\title{
Adsorbent-Adsorbate Pairs for Solar Thermal Energy Storage in Residential Heating Applications: A Comparative Study
}

\author{
Kapil Narwal, R. Kempers, P. G. O’Brien \\ Lassonde School of Engineering \\ York University \\ Toronto, Canada \\ mr.k.narwal@gmail.com, kempers@yorku.ca, paul.obrien@lassonde.yorku.ca
}

\begin{abstract}
This paper investigates the feasibility of using different adsorbent-adsorbate pairs in a thermal energy storage cycle to store solar energy for residential heating applications in Canada. Silica gel, activated carbon, activated aluminum, zeolite-4A, zeolite-5A and zeolite-13X adsorbents paired with methanol and water adsorbates are considered. Calculations are made to determine the volume, mass and cost of the adsorbent-adsorbate pair required to heat a house with four occupants. Zeolite 4A-water and zeolite 13X-water pairs are found to be the most economic (with an actual cost of 285 $\mathrm{CAD}$ and $374 \mathrm{CAD}$, respectively) and efficient (maximum heat of adsorption) adsorbent-adsorbate pairs with the minimum mass required, (290 kg and $226 \mathrm{~kg}$, respectively) to meet the spatial heating requirements of the house.
\end{abstract}

Keywords- Adsorption, adsorption pairs, thermal energy storage

\section{INTRODUCTION}

Policy changes incentivizing sustainable energy technologies have provided new opportunities for renewable sources of energy such as solar, wind, tidal and others. Investments in solar energy, which is abundantly available, has increased exponentially in recent years. However, solar energy is intermittent and should be coupled with energy storage technologies to reach its full potential. For example, one promising technology for utilizing solar energy in a Canadian climate is to store it in a thermal battery so it can be used at night to reduce building heating loads. As solar thermal energy storage costs are considerable, various technologies are being explored to optimize its capacity, operating temperature, and overall performance. Heat energy is stored at different temperatures depending on its intended application. Low temperature heat is useful for domestic air-conditioning applications whereas high temperature heat is extremely useful in industry. Furthermore, heat energy can be stored in various forms: sensible heat (solids, liquids, solid-liquid), latent heat (solid-solid, solid-liquid), chemical heat (reacting solids or liquids, gaseous compounds) and the heat of adsorption or absorption (physisorption, chemisorption, heat of solutions). Sensible heat storage technologies utilize high heat capacity materials, whereas latent heat energy storage technologies absorb/release heat when a material undergoes a phase change from solid to liquid or liquid to gas and vice-versa. On the other hand, chemical heat energy storage technologies utilize reversible thermo-chemical reactions (Rainer et al. 2012) to absorb and release heat. Sorption-based thermal storage technologies can be broadly categorized as absorption and adsorption processes, depending on whether the adsorbate atoms or molecules are dissolved in, or adhered to, the surface of the absorbent. Advantages of sorption-based thermal energy storage technologies are their minimal costs, and matured performance in heat pumping and solar refrigeration. In this article, adsorption-based thermal energy storage materials are investigated for their potential to store solar energy during the day to provide heat at night in a typical Canadian residential home.

\section{LITERATURE REVIEW}

Studies have been conducted to understand thermal energy storage technologies such as electric thermal storage heaters, salt hydrate technology, molten salt technologies and solar energy storage. (Bataineh and Taamneh 2016) conducted a feasibility analysis of both adsorption and absorption systems and concluded that extended adsorption and desorption times, poor exhibitions, and low coefficient of performance (COP) are hindering the widespread commercialization of these technologies. (Papadopoulos et al. 2003) reviewed existing solar energy based sorptive refrigeration technologies for applications in both residential and commercial spaces, and discussed the necessity of implementing energy policies to accelerate the flourishment of solar refrigeration technologies. (Cabeza et al. 2017) presented an exhaustive review on adsorption and absorption technologies in refrigeration and thermal heat storage and discussed research progression 
towards developing efficient working pairs with better storage capacities and optimal energy output. (Aliane et al. 2016) studied various solar energy technologies developed for adsorptive cooling. A comparative study of various experimental systems has been done to study the operative behaviors of individual components and whole systems. It was concluded that these technologies can potentially be extended to meet global energy demands by implementing some modest improvements. Further, (Alobaid et al. 2017) reviewed solar absorption cooling systems which were fifty percent more energy efficient than vapor compression based cooling systems. The COP and thermal collector efficiency of the solar based systems are found to vary from 0.1-0.91 and 0.06-0.64, respectively. It was also noted that solar collector costs comprise a significant portion of the entire system. (Zeyghami et al. 2015) discussed various concepts, designs, and experimental set-ups for thermomechanical solar adsorption systems while discussing performance enhancement approaches. (Goyal et al. 2016) presented the fundamentals of solar energy utilization in adsorption systems and provided a thorough discussion about technological and economic aspects, recognizing that poor heat and mass transfer performances, low COP, and higher costs are the major roadblocks preventing the development of competitive products in this technological field. It has also been observed that hybrid systems, which combine solar adsorption heating and cooling, enhance the system performances significantly. (Askalany et al. 2013) compared various adsorption cooling systems and presented a comparision based on adsorbentrefrigrent pairs on the basis of COP, specific cooling power, driving and evaporation temperatures. It has been observed that the systems employing silica gel-water and chloride composites-water pairs have the highest COP, while those employting zeolite-water pairs have the lowest COP. The lowest evaporation temperatures were found in a system that used metal hydride-water pairs and the lowest driving temperatures were observed for the case of silica-gel-methanol and chloride composites-methanol pairs, wheras the highest driving temperatures are found in zeolite-water pairs.

\section{ADSORPTION}

Adsorption involves the adhesion of adsorbate molecules on the adsorbent surface. The adsorbent is usually a porous material with a high surface area. Adsorbate molecules form a thin film on the surface of the adsorbent either by physisorption or chemisorption. Adsorption is referred to as physisorption if the adsorbate molecules are attached on the adsorbent surface by Vander Waals forces, and chemisorption if the adsorbate molecules are chemically attached at the adsorbent surface. Thermal heat storage, therefore, is a physiochemical phenomenon between the adsorbate and adsorbent molecules while condensation and evaporation facilitate the charging and release of adsorbate molecule onto and from the adsorbent, respectively.

\section{THERMAL ENERGY STORAGE CYCLE}

The thermal energy storage cycle for the application of residential heating in Canada, shown in Figure 1, comprises two main processes: desorption and adsorption.

Desorption process: During the day the solar irradiance provides the heat of adsorption required to drive the evaporation of adsorbate molecules from the adsorber. The average daily solar insolation available from November through March in Toronto, Canada is $7.8 \mathrm{MJ} / \mathrm{m}^{2}$ (October-9.3 $\mathrm{MJ} / \mathrm{m}^{2}$, November-5.1 MJ $/ \mathrm{m}^{2}$, December-4.3 MJ $/ \mathrm{m}^{2}$, January5.7 MJ/m², February-9.2 MJ/m² and March-13.2 MJ/m²) [26]. Assuming the average size of a residential building with four occupants is $200 \mathrm{~m}^{2}$ [27] the net solar radiance available during these cold climatic conditions is $1.56 \mathrm{GJ}$ per day.

Adsorption process: During the night adsorbate molecules that have evaporated from the condenser/evaporator are adsorbed by the adsorbent, and the heat of vaporization is released to function as a heat supply for residential heating. The reaction that occurs during the desorption and adsorption processes can be written as follows:

Adsorbent $+n \cdot$ Adsorbate $\leftrightarrow$ Adsorbent $* n \cdot$ Adsorbate + Heat

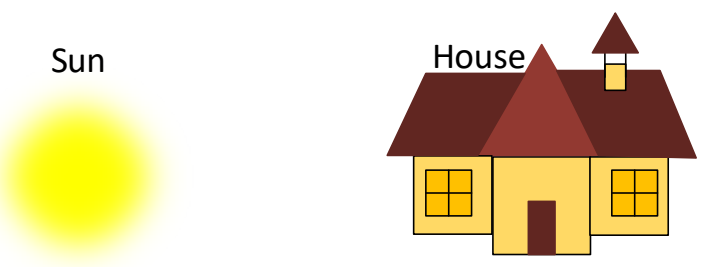

Heat of Vaporization Heat of Condensation
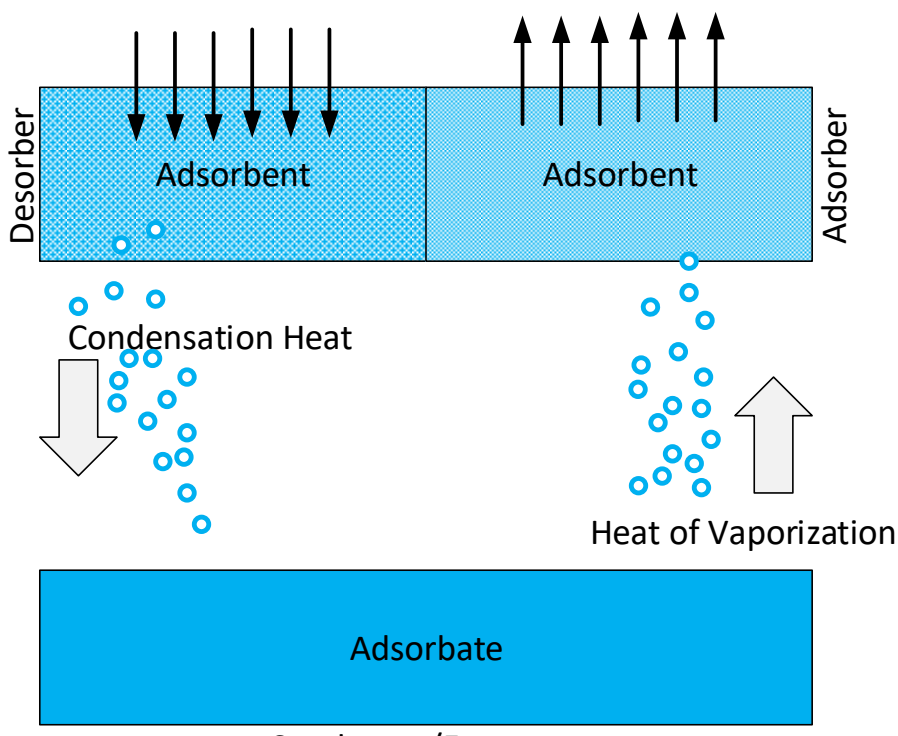

Condenser/Evaporator

Fig 1. Schematic diagram showing the desorption (left) and adsorption (right) processes in the thermal energy adsorption cycle. 


\section{ADSORPTION PAIRS}

The adsorbate and adsorbent form an essential component of the thermal energy storage cycle and various factors play a decisive role in selecting the right pair including the maximum adsorption capacity, heat of adsorption, energy capacity, specific heat of adsorbent, adsorbent density, critical pressure and critical temperature. The maximum adsorption capacity is the maximum amount of adsorbate an adsorbent can adsorb. The heat of adsorption is the heat released during the adsorption process, and can be determined by estimating the heat released in a calorimeter experiment or by adsorption isotherms. The energy capacity is the maximum energy an adsorbent can absorb or release. The specific heat of adsorbent is the heat required to raise the temperature of the adsorbent by one degree under constant pressure. At the critical temperature and critical pressure, the density of the adsorbate liquid and vapor is equal.

While many different adsorbates are available for various applications, the most commonly used are water, ammonia, methanol and ethanol. The latent heat of evaporation of water $(2258 \mathrm{~kJ} / \mathrm{kg})$ is very high compared to that of ammonia (1368 $\mathrm{kJ} / \mathrm{kg})$, methanol (1100 kJ/kg) and ethanol (1100 kJ/kg). Thus, water is typically preferred, although other adsorbates can be used to produce sub-zero temperatures. Activated carbons, zeolites, silica gels, metal-organic frameworks, and potassium hydroxide $(\mathrm{KOH})$ are widely used adsorbents as they have a highly porous structure, which increases the adsorption capacity of the system. (Aristov 2007) presented selective water sorbents based on halides, sulphates and nitrates of alkaline and alkaline earth metals possessing an intermediate behavior between solid adsorbents, salt hydrates, and liquid absorbents. Also, an estimation was made on the thermodynamic equilibrium of these materials with water vapors. These sorbents are found to possess a better COP then silica gel-water and zeolite-water based systems. (Aristov 2013) reviewed existing literature on metalaluminophosphates, metal-organic frameworks, ordered porous solids, and porous carbons and composite frameworks. (Gordeeva and Aristov 2012) surveyed composite salts inside porous matrix (CSPM) sorbents. (Bhargav et al. 2017) studied the methanol-activated carbon fiber adsorption pair, and the adsorption capacity and desorption temperature were investigated under isobaric conditions using the Dubinin-Astakhov equation. (Brancato et al. 2015) tested various activated carbon fibers and composites of $\mathrm{LiBr}$ on silica gel adsorbents along with ethanol as a refrigerant. A thermo-physical analysis including nitrogen physisorption, specific heat and thermo-gravimetric equilibrium has been performed, and the Dubinin-Astakhov equation has been used to fit the equilibrium data. Furthermore, the thermodynamic performance was estimated by calculating the COP. (Erto et al. 2010) studied trichloroethylene adsorbates precipitated from water-based solutions on a set of 12 different activated carbon adsorbents. Results indicated that the adsorption capacity increases with an increase in Brunauer-Emmett-Teller (BET) surface area, micropore volume, and the percentage of carbon in the adsorbent. Further, the presence of sodium and tetrachloroethylene also increased the absorption capacity. (Meng and Park 2010) improved the $\mathrm{CO}_{2}$ adsorption capacity by inserting $\mathrm{KOH}$ in graphite nanofibers to increase its porosity under heat treatment at $700-1000^{\circ} \mathrm{C}$. The heat treatment temperature had a significant effect on the adsorption capacity and texture of graphite nanofibers, and a positive effect on surface area, total pore volume and micropore volume. (Saha et al. 2011) studied the adsorption of an ethanol-MIL101Cr pair theoretically and experimentally within a $0.1-0.9$ bar pressure range and a $30-70^{\circ} \mathrm{C}$ temperature range. One $\mathrm{kg}$ of MIL-101 $\mathrm{Cr}$ is found to adsorb up to $1.1 \mathrm{~kg}$ of ethanol at $30^{\circ} \mathrm{C}$. The Tóth equation has been used to fit experimental data with the goal of enhancing the adsorption capacity in the adsorption cooling cycle employing activated carbon fibers (ACF) as adsorbents. (Saha et al. 2015) studied various adsorbent-refrigerant pairs at a temperature of $77.3 \mathrm{~K}$. ACF (A-20), owing to its large surface area, MIL-101Cr was found to have $0.797 \mathrm{~kg} / \mathrm{kg}$ ethanol adsorption capacity. (Uddin et al. 2014) studied the highly porous Maxsorb III, $\mathrm{H}_{2}$ and $\mathrm{KOH}-\mathrm{H}_{2}$ surface treated Maxsorb III adsorbents for ethanol adsorption at $30-70^{\circ} \mathrm{C}$ and evaporation temperatures of $65^{\circ} \mathrm{C}$ experimentally. The Dubinin-Radushkevich and DubininAstakhov adsorption isotherm models have been used to obtain adsorption isotherms. Adsorption cycle performance studies were conducted using activated carbon-ethanol adsorption pairs. $\mathrm{H}_{2}$ surface treated Maxsorb III exhibits a COP of 0.51 with a specific cooling effect of $374 \mathrm{~kJ} / \mathrm{kg}$ at evaporation, heat source, and heat sink temperatures of $-5^{\circ} \mathrm{C}$, $100^{\circ} \mathrm{C}$ and $30^{\circ} \mathrm{C}$, respectively. (Zeng et al. 2017) studied the ammonia adsorption on four different kinds of activated carbons at $30^{\circ} \mathrm{C}$. MSC30 is found to possess a very high adsorption capacity for ammonia. A modified DubininAstakhov equation has been used for isothermal studies. (Dawoud et al. 2007) experimentally studied an adsorption system using a zeolite 13X-water adsorption pair. It was observed that an increase in the flow rates of the adsorber and desorber increase the heat discharge, while higher temperatures occured at lower flow rates. A radiation shield is found to be effective in minimizing radiation losses during the adsorption process. (Ansari et al. 2014) prepared nano-NaX zeolite using a hydrothermal process. The size and crystallinity of the $\mathrm{NaX}$ zeolites is found to increase up to 44 $\mathrm{nm}$ and $96 \%$, respectively, as the reaction time was increased from $1 \mathrm{~h}$ to $4 \mathrm{~h}$ and the reaction temperature increased from $90^{\circ} \mathrm{C}$ to $110^{\circ} \mathrm{C}$. (Tatler and Erdem-Şenatalar 2004) evaluated the effective diffusion coefficient of water in zeolite-4A coatings. It is observed that the evaluated results qualify the thermogravimetric analysis (TGA) and effective medium theory (EMT) based experimental results from the literature. (Solmuş et al. 2011) developed a zeolite-water pair based adsorption cooling system and investigated its performance at various evaporator temperatures. The COP of the system was about 0.25 at adsorption, desorption, and condenser temperatures of $45^{\circ} \mathrm{C}, 150^{\circ} \mathrm{C}$, and $30^{\circ} \mathrm{C}$, respectively, for evaporative temperatures ranging from $10^{\circ} \mathrm{C}$ to $22.5^{\circ} \mathrm{C}$. The mean volumetric specific cooling power density and the mean 
mass specific cooling power density were found to be 4.8 $\mathrm{kW} / \mathrm{m}^{3}$ and $6.4 \mathrm{~W} / \mathrm{kg}$, respectively. (Solmuş et al. 2010) used the Dubinin-Astakhov equation to determine a maximum adsorption capacity of $0.12 \mathrm{~kg}_{\mathrm{w}} / \mathrm{kg}_{\mathrm{ad}}$ for a natural zeolite. Furthermore, the isosteric heat was calculated and a correlation between adsorption and desorption processes was established.

\section{DISCUSSION}

Herein, different adsorbate-adsorbent pairs are investigated for their ability to store solar energy during the day to provide heating for a typical residential home in Canada. The average size of a residence with four occupants is around $200 \mathrm{~m}^{2}$ [26] with the overall energy requirements of 130 GJ yearly, or 0.36 GJ daily, by Statistics Canada [27], and it is assumed that 63\% of this energy is used for spatial heating [28]. Thus, it is assumed that $0.23 \mathrm{GJ}$ is required for spatial heating, which is much less than the average solar irradiance (1.6 GJ) estimated to be incident on a residential home in Toronto over the months from November to March (Table III).

Different adsorbate-adsorbent pairs comprising seven adsorbents (charcoal, silica gel, activated alumina, zeolie-4A, $5 \mathrm{~A},-13 \mathrm{X}$, and activated carbon) with water and methanol as

TABLE I. THERMOCHEMICAL PROPERTIES OF ADSORBENT-ADSORBATE PAIRS (RAINER ET AL. 2012)

\begin{tabular}{|c|c|c|c|c|c|c|c|c|c|c|}
\hline Material & Adsorbate & $\begin{array}{c}\text { Max. } \\
\text { adsorbate } \\
\text { capacity }\end{array}$ & $\begin{array}{c}\begin{array}{c}\text { Heat of } \\
\text { adsorption } \\
\text { (average) }\end{array} \\
\Delta h_{\text {ads }}\end{array}$ & $\begin{array}{c}\begin{array}{c}\text { Adsorbent } \\
\text { specific } \\
\text { heat }\end{array} \\
\text { Cadsorbent }\end{array}$ & $\begin{array}{l}\text { Net heat of } \\
\text { adsorption }\end{array}$ & $\begin{array}{l}\text { Net Heat of } \\
\text { adsorption per } \\
\text { unit volume of } \\
\text { adsorbent }\end{array}$ & $\begin{array}{l}\text { Volume of } \\
\text { Adsorbent } \\
\text { required for } \\
\text { residential heating }\end{array}$ & $\begin{array}{c}\text { Net } \\
\text { adsorbent } \\
\text { required }\end{array}$ & $\begin{array}{c}\text { Amount of } \\
\text { Adsorbate } \\
\text { required }\end{array}$ & $\begin{array}{l}\text { Total } \\
\text { mass of } \\
\text { system }\end{array}$ \\
\hline & & $\begin{array}{l}\text { kgadsorbate/ } \\
\text { kgadsorbent }\end{array}$ & $\begin{array}{c}\text { kJ/ } \\
\text { kgadsorbate }\end{array}$ & $\mathrm{kJ} \mathrm{kg}^{-1} \mathrm{~K}^{-1}$ & $\begin{array}{c}\text { kJ/ } \\
\text { kgadsorbent }\end{array}$ & $\mathrm{kJ} / \mathrm{m}^{3}$ & $\mathrm{~m}^{3}$ & kg & kg & kg \\
\hline Charcoal & Water & 0.4 & 2320 & 1.09 & 928 & 445440 & 0.52 & 247.84 & 99.14 & 346.98 \\
\hline Silica gel & Water & 0.37 & 2560 & 0.88 & 947.2 & 634624 & 0.36 & 242.82 & 89.84 & 332.66 \\
\hline Activated alumina & Water & 0.19 & 2480 & 1 & 471.2 & 461776 & 0.50 & 488.12 & 92.74 & 580.86 \\
\hline Zeolites 4A & Water & 0.22 & 4410 & 1.05 & 970.2 & 756756 & 0.30 & 237.06 & 52.15 & 289.22 \\
\hline Zeolites 5A & Water & 0.22 & 4180 & 1.05 & 919.6 & 625328 & 0.37 & 250.11 & 55.02 & 305.13 \\
\hline Zeolites $13 \mathrm{X}$ & Water & 0.3 & 4410 & 0.92 & 1323 & 793800 & 0.29 & 173.85 & 52.15 & 226.00 \\
\hline Active carbon & Methanol & 0.32 & 1400 & 0.9 & 448 & - & - & - & - & - \\
\hline Zeolites 4A & Methanol & 0.16 & 2300 & 1.05 & 368 & 287040 & 0.80 & 625.00 & 100.00 & 725.00 \\
\hline Zeolites 5A & Methanol & 0.17 & 2300 & 1.05 & 391 & 265880 & 0.87 & 588.24 & 100.00 & 688.24 \\
\hline Zeolites $13 \mathrm{X}$ & Methanol & 0.2 & 2400 & 0.92 & 480 & 288000 & 0.80 & 479.17 & 95.83 & 575.00 \\
\hline
\end{tabular}

TABLE II. THERMODYNAMIC PROPERTIES OF ADSORBATES FOR ADSORPTION COOLING AND HEATING [17]

\begin{tabular}{|c|c|c|c|c|c|}
\hline & Mol wt. & $\begin{array}{c}\text { Critical } \\
\text { temp. }\end{array}$ & $\begin{array}{c}\text { Critical } \\
\text { pressure }\end{array}$ & Density & Specific heat \\
\cline { 2 - 6 } & & $\mathbf{T}_{\text {cr }}$ & $\mathbf{P}_{\text {cr }}$ & $\boldsymbol{\rho}_{\text {cr }}$ & $\mathbf{C}_{\mathrm{p} 0 \text {,cr }}$ \\
\hline Methanol & 32.042 & $\mathbf{K}$ & $\mathbf{k P a}$ & $\mathbf{m o l ~ m}^{-3}$ & $\mathbf{k J ~ m o l}^{-1} \mathbf{K}^{-1}$ \\
\hline Ethanol & 46.069 & 512.64 & 8140 & 8547 & 0.061 \\
\hline Ammonia & 17.031 & 405.65 & 11300 & 13889 & 0.038 \\
\hline Water & 18.015 & 647.3 & 22048 & 17857 & 0.037 \\
\hline 1-Propanol & 60.096 & 536.78 & 5120 & 4545 & 0.135 \\
\hline 2-Propanol & 60.096 & 508.3 & 4790 & 4525 & 0.133 \\
\hline
\end{tabular}

properties of adsorbate-adsorbent pairs are listed in Table I. The adsorbate capacity (figure 3 ) for the adsorbents considered herein varies from $0.16-0.37 \mathrm{~kg}$ adsorbate $/ \mathrm{kg}_{\text {adsorbent, }}$ with the silica gel-water having the maximum followed by active-carbon at $0.32 \mathrm{~kg}_{\text {adsorbate }} / \mathrm{kg}_{\text {adsorbent }}$ and zeolite- $13 \mathrm{X}$ at 0.3 $\mathrm{kg}_{\text {adsorbate }} / \mathrm{kg}_{\text {adsorbent }}$ whereas the heat of adsorption (figure 4) of zeolite is the largest with a value of $1400-4410 \mathrm{~kJ} / \mathrm{kg}_{\text {adsorbate }}$. Here the zeolite 4A-water and zeolite 13X-water pairs show high potential with energy capacities of 970 and 1320 $\mathrm{kJ} / \mathrm{kg}_{\text {adsorbent, }}$ respectively, which is the largest amongst all pairs considered. Thermodynamic properties viz. molecular weight, critical temperature, critical pressure, density and specific heat of some selective adsorbates for adsorption based cooling and heating are given in Table II. Further, Table I shows the net heat of adsorption (figure 8) per mass of adsorbent is the largest for zeolite 4A-water and zeolite 13X- 


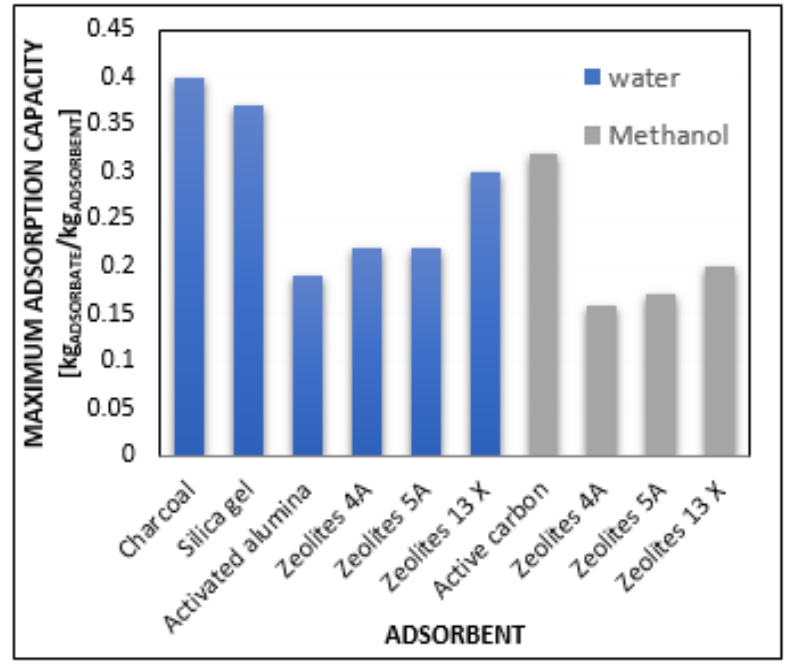

Fig 2. Maximum adsorption capacity of various adsorbents

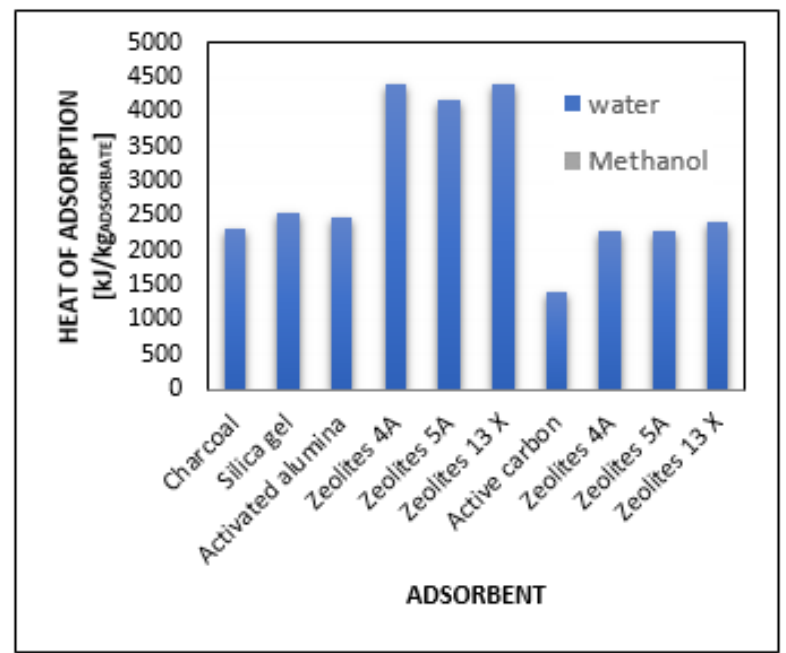

Fig 3. Heat of adsorption generated with one kilogram of various adsorbents

TABLE III. AVERAGE ENERGY REQUIREMENTS OF A HOUSE OF FOUR IN CANADA [SOURCE: STATISTICS CANADA]

\begin{tabular}{|l|c|}
\hline For a house of $\mathbf{4}$ occupants with an area $\mathbf{2 0 6 . 4} \mathbf{~ m}^{\mathbf{2}}$ & GJ \\
\hline Average energy requirement yearly & 130 \\
\hline Average energy requirement per Day & 0.36 \\
\hline $\begin{array}{l}\text { Average energy requirement for spatial heating per } \\
\text { Day }\end{array}$ & 0.23 \\
\hline $\begin{array}{l}\text { Average solar energy available per day in Toronto } \\
\text { (November-March) }\end{array}$ & 1.56 \\
\hline
\end{tabular}

water with values of 970 and $1323 \mathrm{~kJ} / \mathrm{kg}_{\text {adsorbent }}$, respectively. The total volume of adsorbent required to provide heating for a residential building with four occupants in Canada using a zeolite 4A-water pair is $0.30 \mathrm{~m}^{3}$, while the volume would be $0.29 \mathrm{~m}^{3}$ if a zeolite $13 \mathrm{X}$-water pair were to be used. If a zeolite

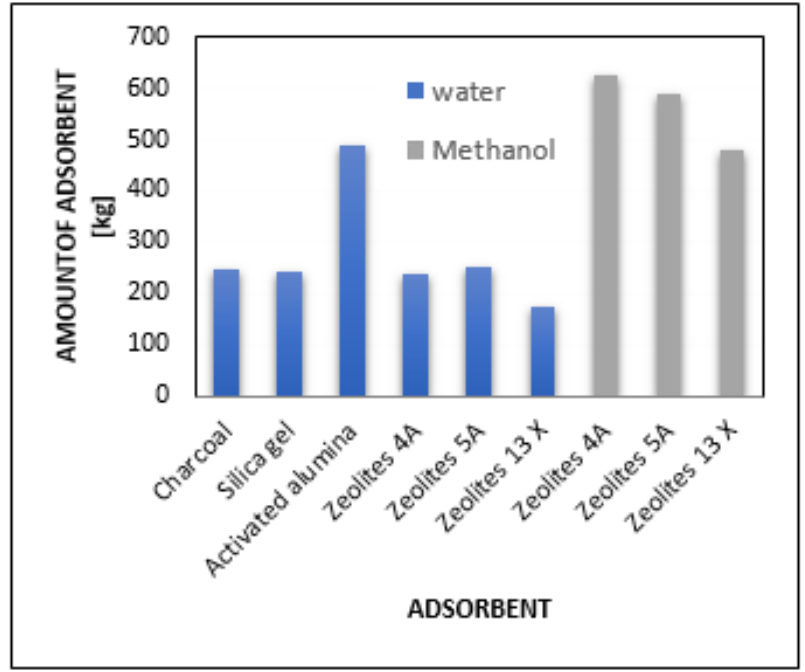

Fig 4. Amount of adsorbents needed to meet the energy requirements for a house with four occupants in Canada

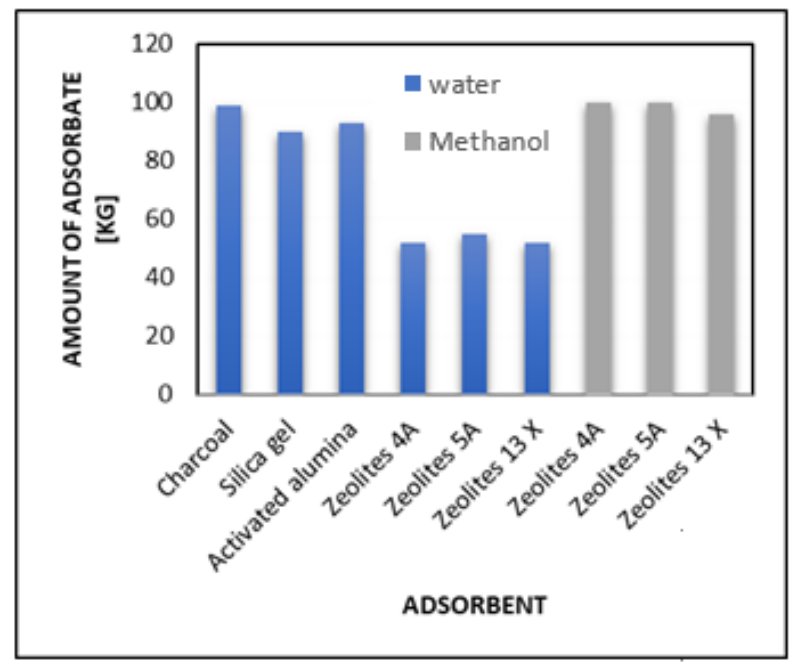

Fig 5. Amount of adsorbate needed to meet the energy requirements for a house with four occupants in Canada

5A-methanol pair were used as the adsorbent/adsorbate then the required volume would increase significantly to $0.87 \mathrm{~m}^{3}$. Also, zeolite 4A-water and zeolite $13 \mathrm{X}$-water pairs have the minimum mass of adsorbent (figure 5) and adsorbate (figure 6) required. The total mass of the adsorption system including both adsorbent and adsorbate needed to meet the energy requirement of the house under consideration for zeolite 4Awater and zeolite 13X-water is $290 \mathrm{~kg}$ and $226 \mathrm{~kg}$, respectively. Now, if the adsorbent-absorbent pair is situated inside flat rectangular panels that are $1.7 \mathrm{~m}$ long, $1 \mathrm{~m}$ wide and $3 \mathrm{~cm}$ thick, it would take only 6 panels of zeolite 4A-water and 6 panels of zeolite 13X-water pairs to meet the spatial heating requirements. The total cost of the adsorbents in discussion is shown in Figure 9 and the cost of zeolite 4A and zeolite $13 \mathrm{X}$ adsorbents required to meet the energy for the house under consideration is $285 \mathrm{CAD}$ and $375 \mathrm{CAD}$, 


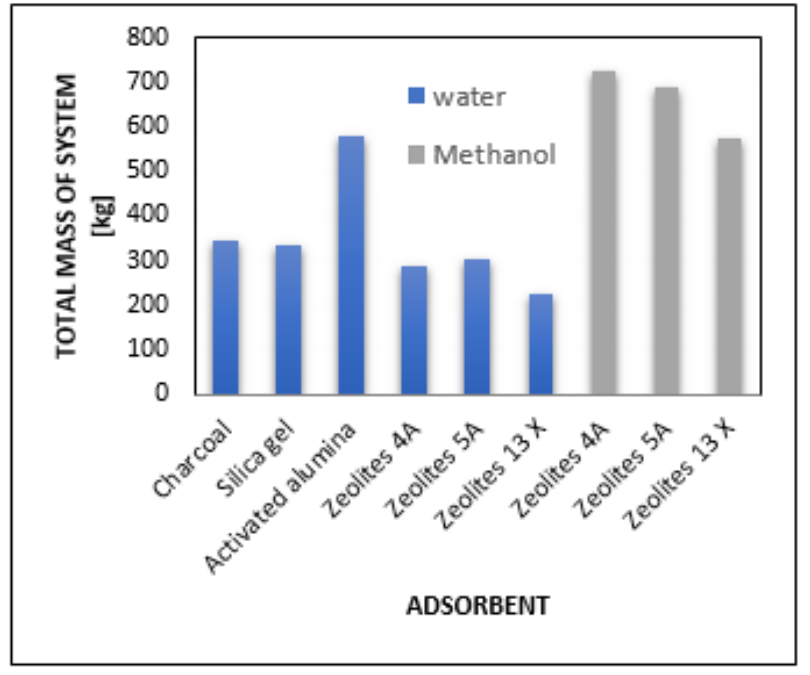

Fig 6. Total mass of the system (adsorbent and adsorbate) needed to meet the energy requirements for a house with four occupants in Canada

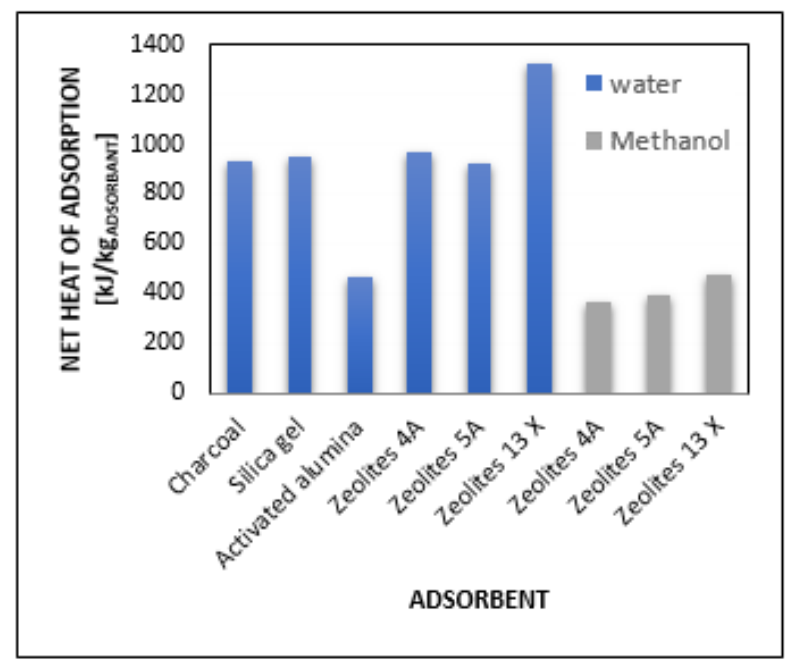

Fig 7. Net Heat of adsorption of various adsorbents

In comparison, an average of about $6.2 \mathrm{~m}^{3}$ [29] of natural gas per day is required to meet the spatial heating requirements for the residence under consideration, and the daily cost of using natural gas for spatial heating would be about 0.6 CAD. Further, assuming a carbon tax of 1 CAD per GJ [31] of energy produced, this cost would rise from 0.6 CAD to 0.85 CAD daily ( 19 CAD monthly). Thus, the owner of the residence under consideration would be able to save $\sim 155$ $\mathrm{CAD}$ on their natural gas heating bill over the colder seasons of the year by using adsorptive technology to heat their home. Perhaps more importantly, considering $\mathrm{CO}_{2}$ emissions, $1 \mathrm{GJ}$ of energy generation from natural gas emits approximately $56 \mathrm{~kg}$ of $\mathrm{CO}_{2}$ [30]. For the residence with four occupants and a daily energy requirement of $0.23 \mathrm{GJ}, \sim 13 \mathrm{~kg}$ of $\mathrm{CO}_{2}$ is emitted daily to provide for heating. Thus, about 2.4 tonnes of $\mathrm{CO}_{2}$ emissions could potentially be prevented by heating a typical

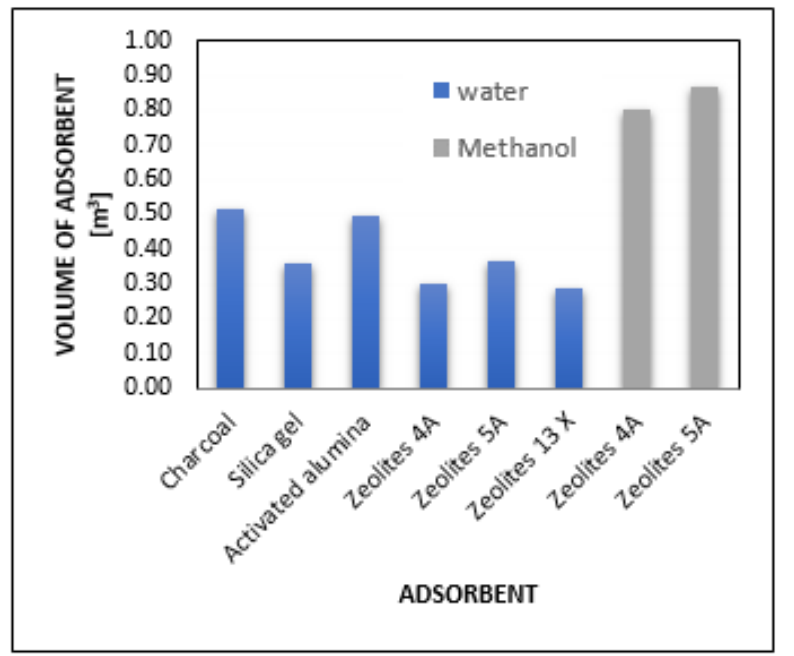

Fig 8. Volume of adsorbents needed to meet the energy requirements for a house with four occupants in Canada

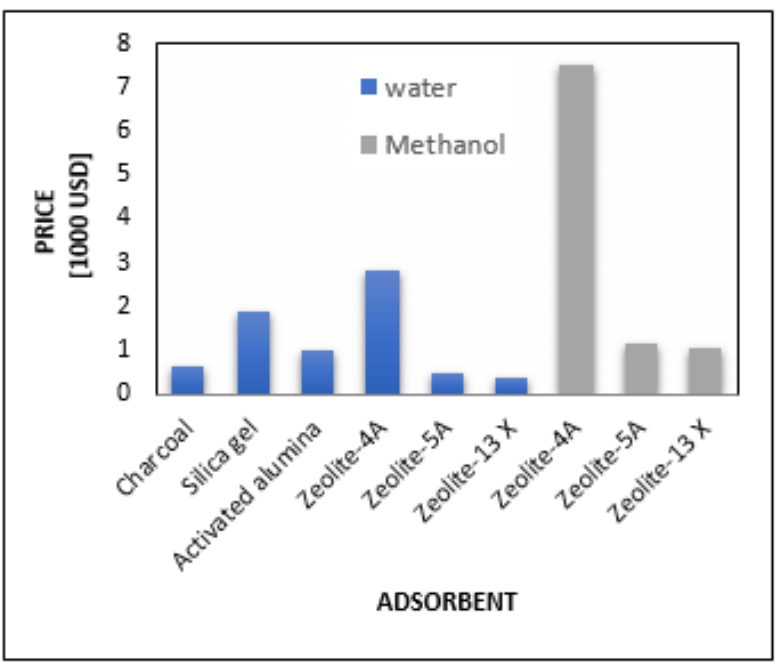

Fig 9. Costs of various adsorbents

Canadian residence using a thermal energy storage cycle based on adsorbate-adsorbent pairs instead of using natural gas. As $\mathrm{CO}_{2}$ emissions per capita in Ontario are $\sim 15$ tonnes, further research and development of sorption-based thermal energy storage cycles that store solar energy for residential heating applications is warranted.

\section{CONCLUSION}

Various adsorbent-adsorbate pairs have been investigated as the working pair in a thermal energy adsorption cycle that provides the energy required to heat a residence with four occupants in Canada. Amongst all pairs considered, the zeolite $4 \mathrm{~A}$-water and zeolite $13 \mathrm{X}$-water pairs have the maximum heat of adsorption and the minimum mass $(290 \mathrm{~kg}$ and $226 \mathrm{~kg}$, respectively) required to meet the heating demands. The net volume of zeolite $4 \mathrm{~A}$ and zeolite $13 \mathrm{X}$ required to meet the spatial heating requirements of the residence is $0.29 \mathrm{~m}^{2}$ and 
$0.30 \mathrm{~m}^{2}$, respectively. The cost of zeolite $4 \mathrm{~A}$ and zeolite $13 \mathrm{X}$ adsorbents for meeting the heating energy requirements of the residence is $285 \mathrm{CAD}$ and $374 \mathrm{CAD}$, respectively. Thus, zeolite 4A-water and zeolite $13 \mathrm{X}$-water pairs can potentially be used in a thermal energy adsorption cycle that stores solar energy so it can be used to provide heating for a residential home in Canada and further research in this area is warranted.

\section{ACKNOWLEDGEMENTS}

This research was supported by the Natural Sciences and Engineering Research Council of Canada

\section{REFERENCES}

[1] Aliane A, Abboudi S, Seladji C, Guendouz B (2016) An illustrated review on solar absorption cooling experimental studies. Renew Sustain Energy Rev 65:443-458. doi: 10.1016/j.rser.2016.07.012

[2] Alobaid M, Hughes B, Calautit JK, et al (2017) A review of solar driven absorption cooling with photovoltaic thermal systems. Renew Sustain Energy Rev 76:728-742. doi: 10.1016/j.rser.2017.03.081

[3] Ansari M, Aroujalian A, Raisi A, et al (2014) Preparation and characterization of nano- $\mathrm{NaX}$ zeolite by microwave assisted hydrothermal method. Adv Powder Technol 25:722-727. doi: 10.1016/j.apt.2013.10.021

[4] Aristov YI (2007) New family of solid sorbents for adsorptive cooling: Material scientist approach. J Eng Thermophys 16:63-72. doi: $10.1134 / \mathrm{S} 1810232807020026$

[5] Aristov YI (2013) Challenging offers of material science for adsorption heat transformation: A review. Appl Therm Eng 50:1610-1618. doi: 10.1016/j.applthermaleng.2011.09.003

[6] Askalany AA, Salem M, Ismael IM, et al (2013) An overview on adsorption pairs for cooling. Renew Sustain Energy Rev 19:565-572. doi: 10.1016/j.rser.2012.11.037

[7] Bataineh K, Taamneh Y (2016) Review and recent improvements of solar sorption cooling systems. Energy Build 128:22-37. doi: 10.1016/j.enbuild.2016.06.075

[8] Bhargav H, Ramani BM, Siva Reddy V (2017) Experimental investigation on adsorption capacity of ACF-methanol pairs for cooling application. Int J Ambient Energy 750:1-4. doi: 10.1080/01430750.2017.1318787

[9] Brancato V, Frazzica A, Sapienza A, et al (2015) Ethanol adsorption onto carbonaceous and composite adsorbents for adsorptive cooling system. Energy 84:177-185. doi: 10.1016/j.energy.2015.02.077

[10] Cabeza LF, Solé A, Barreneche C (2017) Review on sorption materials and technologies for heat pumps and thermal energy storage. Renew Energy. 110:3-39. doi: 10.1016/j.renene.2016.09.059

[11] Dawoud B, Amer E, Gross D (2007) Experimental investigation of an adsorptive thermal energy storage. Int J energy Res 31:135-147. doi: $10.1002 / \mathrm{er}$

[12] Erto A, Andreozzi R, Lancia A, Musmarra D (2010) Factors affecting the adsorption of trichloroethylene onto activated carbons. Appl Surf Sci 256:5237-5242. doi: 10.1016/j.apsusc.2009.12.110

[13] Gordeeva LG, Aristov YI (2012) Composites "salt inside porous matrix" for adsorption heat transformation: A current state-of-the-art and new trends. Int J Low-Carbon Technol. 7:288-302 doi: 10.1093/ijlct/cts050
[14] Goyal P, Baredar P, Mittal A, Siddiqui AR (2016) Adsorption refrigeration technology - An overview of theory and its solar energy applications. Renew Sustain Energy Rev 53:1389-1410. doi: 10.1016/j.rser.2015.09.027

[15] Meng LY, Park SJ (2010) Effect of heat treatment on CO2 adsorption of $\mathrm{KOH}$-activated graphite nanofibers. J Colloid Interface Sci 352:498503. doi: $10.1016 /$ j.jcis.2010.08.048

[16] Papadopoulos AM, Oxizidis S, Kyriakis N (2003) Perspectives of solar cooling in view of the developments in the air-conditioning sector. Renew Sustain Energy Rev 7:419-438. doi: 10.1016/S13640321(03)00063-7

[17] Rainer T, Thomas B, Erich H (2012) Heat Storage Media. Ullmann's Encycl Ind Chem 421-438. doi: 10.1002/14356007.a12

[18] Saha BB, El-Sharkawy II, Miyazaki T, et al (2015) Ethanol adsorption onto metal organic framework: Theory and experiments. Energy 79:363-370. doi: 10.1016/j.energy.2014.11.022

[19] Saha BB, Koyama S, El-sharkawy II, et al (2011) Experiments for measuring adsorption characteristics of an activated carbon fiber, ethanol pair using a plate-fin heat exchanger. 12:S2, 767-782 doi.org/10.1080/10789669.2006.10391206

[20] Solmuş I, Kaftanoĝlu B, Yamali C, Baker D (2011) Experimental investigation of a natural zeolite-water adsorption cooling unit. Appl Energy 88:4206-4213. doi: 10.1016/j.apenergy.2011.04.057

[21] Solmuş I, Yamali C, Kaftanoğlu B, et al (2010) Adsorption properties of a natural zeolite-water pair for use in adsorption cooling cycles. Appl Energy 87:2062-2067. doi: 10.1016/j.apenergy.2009.11.027

[22] Tatler M, Erdem-Şenatalar A (2004) Estimation of the effective diffusion coefficients in open zeolite coatings. Chem Eng J 102:209216. doi: 10.1016/j.cej.2004.04.001

[23] Uddin K, El-sharkawy II, Miyazaki T, et al (2014) Thermodynamic Analysis of Adsorption Refrigeration Cycles Using Parent and Surface Treated Maxsorb III / Ethanol Pairs Interdisciplinary graduate school of engineering sciences, Kyushu University, Interdisciplinary graduate school of engineering science. 1-10

[24] Zeng T, Huang H, Kobayashi N, Li J (2017) Performance of an Activated Carbon-Ammonia Adsorption Refrigeration System. Nat Resour 8:611-631. doi: 10.4236/nr.2017.810039

[25] Zeyghami M, Goswami DY, Stefanakos E (2015) A review of solar thermo-mechanical refrigeration and cooling methods. Renew Sustain Energy Rev 51:1428-1445. doi: 10.1016/j.rser.2015.07.011

[26] Natural Resources Canada, Photovoltaic and solar resource mapsphotovoltaic potential and insolation dataset. http://www.nrcan.gc.ca/18366

[27] Statistics Canada (2007) Households and the Environment Use, Cat no. 11-526-S https://www.statcan.gc.ca/pub/11-526-s/11-526-s2010001eng.pdf

[28] Office of Energy Efficiency (2011), Energy Efficiency Trends in Canada 1990-2009, Cat. No. M141-1/2009E, ISSN 1926-8254 Page-12 http://oee.rncan.gc.ca/publications/statistics/trends11/pdf/trends.pdf

[29] Macleans, economic analysis article- The cost of carbon pricing in Ontario and Alberta, http://www.macleans.ca/economy/economicanalysis/what-carbonprices-in-alberta-and-ontario-will-cost-the-average-household-and-why/

[30] Natural Resourses Canada, Energy, Energy Sources and Distribution, Natural Gas: A Primer, https://www.nrcan.gc.ca/energy/natural-gas/5641

[31] Natural Resources Canada, Energy Use in the Canadian Steel Industry Study - Table of Contents, Appendix B - CO2 Emission Factors, http://www.nrcan.gc.ca/energy/efficiency/industry/technicalinfo/benchmarking/canadian-steel-industry/519 